\title{
Enterprise Resource Planning System Implementation: a User Perspective
}

\author{
Ewout Reitsma \\ Department of Industrial Engineering and Management, School of Engineering \\ Jönköping University, P.O. Box 1026, SE-551 11, Jönköping, Sweden \\ E-mail: ewout.reitsma@ju.se (Corresponding Author) \\ Per Hilletofth \\ Department of Industrial Engineering and Management, School of Engineering \\ Jönköping University, P.O. Box 1026, SE-551 11, Jönköping, Sweden \\ Department of Industrial Engineering and Management, School of Engineering \\ University of Gävle, SE-801 76, Gävle, Sweden \\ E-mail: prof.p.hilletofth@gmail.com
}

\author{
Umer Mukhtar \\ Department of Management Sciences \\ GIFT University, Punjab, Pakistan \\ E-mail: umer-mukhtar@live.com
}

\begin{abstract}
The purpose of this study is to evaluate critical success factors (CSFs) for the implementation of an enterprise resource planning (ERP) system from a user perspective. Users play a vital role when implementing an ERP system, but their perspective has been neglected in the literature. A better understanding of their perspective promises to contribute to the design of more effective ERP systems, its implementation, and management. In order to identify the user perspective, a survey was conducted within three organizations from Pakistan that have recently implemented an ERP system. The questionnaire was developed based on thirteen CSFs deduced from literature. Based on each CSF's level of importance, they are ranked in order of importance and divided into three groups: most important, important and not important. Findings reveal that users of the three organizations in Pakistan believe that the implementing organization should prioritize the following four CSFs when implementing an ERP system: education and training, strategic decision-making, communication, and business process alignment.
\end{abstract}

Keywords: ERP, user perspective, critical success factors

\section{INTRODUCTION}

Supply chain management is of major importance in most industries. In essence, it concerns collection and analysis of data to provide better basis for decision-making (Hilletofth \& Lättilä, 2012). Information systems are needed to achieve this due to complex supply chain structures and processes (Hilletofth, 2008). One information system that has been central in operating and managing supply chains is the enterprise resource planning (ERP) system (Hilletofth et al., 2010). Despite ERP systems becoming a fundamental tool in many industries, the rate of failure in their implementation is high (Huang et al., 2004; Mu et al., 2015).
The reasons for failure have been widely discussed in the literature and research concentrates on identifying the conditions that are believed to increase the probability of success of an implementation project. These conditions are referred to as critical success factors (CSFs) and are mostly discussed from a generic perspective (Reitsma \& Hilletofth, 2018). Understanding these CSFs and how they influence the project outcome decreases the risks of failure, and provide helpful guidance for organizations (Huang et al., 2004). Within this specific research field, very limited empirical studies have been conducted that investigate the user perspective towards CSFs for ERP system implementation (Reitsma \& Hilletofth, 2018; Young et al., 2012). Even though a comprehensive investigation of the user perspective is lacking within this specific research field, studies do stress the importance of user involvement during system implementation (Fearon et al., 2013; Ziemba \& Oblak, 2013).

The purpose of this study is to evaluate CSFs for ERP system implementation from a user perspective. A better understanding of this perspective promises to contribute to the ERP system's design, implementation, and management (Fearon et al., 2013; Eichhorn \& Tukel, 2016; Ziemba \& Oblak, 2013). Previous research has focused on one manufacturer from Germany (Reitsma \& Hilletofth, 2018) and thus there is a need to extend the research to other industries and countries. This study extends the research by distributing a survey within three organizations from Pakistan that have recently implemented an ERP system, which was developed based on the 13 CSFs proposed by Reitsma and Hilletofth (2018). Case organization $\alpha$ operates in the education industry, case organization $\beta$ operates in the manufacturing industry, and case organization $\gamma$ operates in the beverages industry. 
The remainder of this paper is structured as follows: To begin with, a theoretical framework consisting of $13 \mathrm{CSFs}$ for ERP system implementation and the user perspective is provided in Section 2. After that, the research method is further explained and motivated in Section 3. Thereafter, the empirical findings are presented and discussed in Section 4. Finally, the research is concluded in Section 5.

\section{THEORETICAL FRAMEWORK}

Within the study of Reitsma and Hilletofth (2018), seven CSFs were regarded as 'most important' for ERP system implementation by users. Users regarded the CSF 'project team' as most important for ERP system implementation. This finding of Reitsma and Hilletofth (2018) validates studies that discuss CSFs from a generic perspective (e.g., Dezdar \& Sulaiman, 2009; Upadhyay \& Dan, 2009; Wang et al., 2008), which indicates that users believe that the project team needs to include the best employees from different functions within the organization and external consultants when in-house ERP system knowledge is missing. Furthermore, they argue that users want a project champion to be included in the project team. This project champion should address the organization's business needs and orchestrate the allocation of resources.

Users regarded the CSF 'technical possibilities' as second most important for ERP system implementation. This finding of Reitsma and Hilletofth (2018) validates studies that discuss CSFs from a generic perspective (e.g., Aloini et al., 2007; Dezdar \& Sulaiman, 2009; Motwani et al., 2005), which indicates that users believe that the implementing organization needs to evaluate the ERP systems offered in the marketplace based on organization strategy, size, business field, its business processes and its internal and external relationship structure. They further argue that users understand the importance of the system's ability to facilitate their daily jobs. Their statement contradicts the study of Chang et al. (2014), who proposed that users deem it unlikely that an ERP package can negatively affect the system's implementation.

Users regarded the CSF 'strategic decision-making' as third most important for ERP system implementation. This finding of Reitsma and Hilletofth (2018) validates studies that discuss CSFs from a generic perspective (e.g., Dezdar \& Sulaiman, 2009; Motwani et al., 2005; Wang et al., 2008), which indicates that users believe that the implementing organization should create a well-defined business plan that envisions how the organization operates behind the ERP system's implementation effort and outlines the proposed strategic and tangible benefits, resources, costs, risks, and timeline. They also propose that users prefer a strategic approach to ERP system implementation, as it provides an understanding of the affects, purpose and benefits of the new system.
Users regarded the CSF 'education and training' as fourth most important for ERP system implementation. This finding of Reitsma and Hilletofth (2018) validates studies that discuss CSFs from a generic perspective (e.g., Aloini et al., 2007; Dezdar \& Sulaiman, 2009; Sherer \& Alter, 2004), which indicates that users believe that the implementing organization needs invests in education and sufficient training in the beginning of the ERP system implementation. They further argue that users understand the purpose of training, as they expect this enhances their confidence and understanding of the ERP system. The finding of Reitsma and Hilletofth (2018) differs from the study of Woo (2007), who argues that users regard training as not important and they only attend the training because they were forces by senior managers.

Users regarded the CSF 'minimum customization' as fifth most important for ERP system implementation. This finding of Reitsma and Hilletofth (2018) validates studies that discuss CSFs from a generic perspective (e.g., Akkermans \& van Helden, 2002; Saini et al., 2013; Ziemba $\&$ Oblak, 2013), which indicates that users believe that all departments need to have the same access to the same data and ERP system and that the chosen ERP system should not be rearranged. Their statement contradicts the studies of Chang et al. (2014) and Snider et al. (2009), who state that users believe that it is unlikely that customization can negatively impact ERP system implementation.

Users regarded the CSF 'software testing' as sixth most important for ERP system implementation. This finding of Reitsma and Hilletofth (2018) validates studies that discuss CSFs from a generic perspective (e.g., Dezdar \& Sulaiman, 2009; Sherer \& Alter, 2004; Singla \& Goyal, 2006), which indicates that users believe that the implementing organization needs to enforce rigorous and sophisticated testing of the software in order to simplify ERP system implementation. They further imply that users will spend more time on testing and improving an information system when there is a strong relationship of trust with developers.

Users regarded the CSF 'performance measurement' as seventh most important for ERP system implementation. This finding of Reitsma and Hilletofth (2018) validates studies that discuss CSFs from a generic perspective (e.g., Dezdar \& Sulaiman, 2009; Motwani et al., 2005; Wang et al., 2008), which indicates that users believe that the implementing organization needs to identify performance measurements, manage expectations, keep track of all occurrences, and to measure the achievements against the milestones and targets. They also state that this finding implies that users expect benefits to be shared with when participating during information system implementation. However, the finding of Reitsma and Hilletofth (2018) contradicts the work of Amoako-Gyampah (2004), who stated that users prefer that senior managers do not focus on performance measures. 
Table 1 CSFs for ERP system implementation, based on Reitsma and Hilletofth (2018)

\begin{tabular}{|c|c|c|c|}
\hline CSF & Code & $\begin{array}{l}\text { User } \\
\text { Label }\end{array}$ & Definition \\
\hline Project team & CSF1 & $\begin{array}{l}\text { Most } \\
\text { important }\end{array}$ & $\begin{array}{l}\text { The project team needs to consist of the best people and has to include a } \\
\text { project champion, employees from different functions and levels, and external } \\
\text { consultants when ERP expertise is missing internally. }\end{array}$ \\
\hline Top management involvement & CSF2 & $\begin{array}{l}\text { Not } \\
\text { important }\end{array}$ & $\begin{array}{l}\text { Top management should reinforce the commitment of all employees in the } \\
\text { organization and create policies that determine and approve new organization } \\
\text { structures, roles, and responsibilities. }\end{array}$ \\
\hline Strategic decision-making & CSF3 & $\begin{array}{l}\text { Most } \\
\text { important }\end{array}$ & $\begin{array}{l}\text { A well-defined business plan and vision should define how the organization } \\
\text { operates behind the implementation effort and has to outline proposed } \\
\text { strategic and tangible benefits, resources, costs, risks and timeline is critical. }\end{array}$ \\
\hline Communication & CSF4 & Important & $\begin{array}{l}\text { Effective communication should be established at every level in the } \\
\text { organization and has to include the formal promotion of the project and its } \\
\text { teams and advertisement of project progress. }\end{array}$ \\
\hline Project management & CSF5 & Important & $\begin{array}{l}\text { Project management should include a clear definition of objectives, } \\
\text { development of both a work and a resource plan has to focus on the } \\
\text { identification of the equipment required to operate the system. }\end{array}$ \\
\hline Vendor support & CSF6 & Important & $\begin{array}{l}\text { Vendor support should be established in the form of technical assistance, } \\
\text { maintenance, and updates, which has to be facilitated by a committed vendor } \\
\text { that oversees the entire implementation's life cycle. }\end{array}$ \\
\hline Minimum customization & CSF7 & $\begin{array}{l}\text { Most } \\
\text { important }\end{array}$ & $\begin{array}{l}\text { Departments should not rearrange the chosen ERP system in order to prevent } \\
\text { interdepartmental issues and should have access to the same data and } \\
\text { system. }\end{array}$ \\
\hline $\begin{array}{l}\text { Organizational change } \\
\text { management }\end{array}$ & CSF8 & $\begin{array}{l}\text { Not } \\
\text { important }\end{array}$ & $\begin{array}{l}\text { The organization should utilize change management techniques and tools that } \\
\text { must be defined and evaluated with the best practices in the industry. }\end{array}$ \\
\hline Business process alignment & CSF9 & Important & $\begin{array}{l}\text { A catalogue of best business processes should be selected and followed to } \\
\text { stay on the right track and avoid conflicts with the procedural rigidity of an ERP } \\
\text { system. }\end{array}$ \\
\hline Software testing & CSF10 & $\begin{array}{c}\text { Most } \\
\text { important }\end{array}$ & $\begin{array}{l}\text { The organization should establish rigorous and sophisticated testing of the } \\
\text { software in order to simplify the ERP system's implementation. }\end{array}$ \\
\hline Performance measurement & CSF11 & $\begin{array}{l}\text { Most } \\
\text { important }\end{array}$ & $\begin{array}{l}\text { Performance measurements should be identified to manage expectations, } \\
\text { keep track of all occurrences and to measure the achievements against the } \\
\text { milestones and targets. }\end{array}$ \\
\hline Education and training & CSF12 & $\begin{array}{l}\text { Most } \\
\text { important }\end{array}$ & $\begin{array}{l}\text { Education and sufficient training requires investment, promotes an effective } \\
\text { and correct use of the ERP system, and should be provided for users from the } \\
\text { beginning of the ERP system implementation project. }\end{array}$ \\
\hline Technical possibilities & CSF13 & $\begin{array}{l}\text { Most } \\
\text { important }\end{array}$ & $\begin{array}{l}\text { All kinds of differences in ERP systems offered in the marketplace should be } \\
\text { evaluated based on its own strategy, size, business field, its business } \\
\text { processes, and its internal and external relationship structure. }\end{array}$ \\
\hline
\end{tabular}

Within the study of Reitsma and Hilletofth (2018), four CSFs were regarded as 'important' for ERP system implementation by users. The first CSF that was regarded as important by users is 'business process alignment'. This finding of Reitsma and Hilletofth (2018) validates studies that discuss CSFs from a generic perspective (e.g., Dezdar \& Sulaiman, 2009; Motwani et al., 2005; Sherer \& Alter, 2004), which indicates that users believe that the implementing organization needs to select and follow a catalogue of best business processes to stay on the right track and avoid conflicts with the procedural rigidity of an ERP system.

The second CSF that was regarded as important by users is 'project support'. This finding of Reitsma and Hilletofth (2018) validates studies that discuss CSFs from a generic perspective (e.g., Dezdar \& Sulaiman, 2009; Wang et al., 2008; Singla \& Goyal, 2006), which indicates that users believe that the implementing organization needs to establish project support in the form of technical assistance, maintenance, and updates, which has to be facilitated by a committed partner that oversees the entire implementation's life cycle.

The third CSF that was regarded as important by users is 'project management'. This finding of Reitsma and Hilletofth (2018) validates studies that discuss CSFs from a generic perspective (e.g., Aloini et al., 2007; Dezdar \& Sulaiman, 2009; Singla \& Goyal, 2006), which indicates that users believe that the implementing organization should include a clear definition of objectives, development of both a work and a resource plan that has to focus on the identification of the equipment required to operate the system.

The fourth CSF that was regarded as important by users is 'communication'. This finding of Reitsma and Hilletofth (2018) validates studies that discuss CSFs from a generic perspective (e.g., Aloini et al., 2007; Dezdar \& Sulaiman, 2009; Motwani et al., 2005), which indicates that users believe that the implementing organization needs to establish effective communication at every organizational level and has to include the formal promotion of the project and its teams and advertisement of project progress. 
Within the study of Reitsma and Hilletofth (2018), two CSFs were regarded as 'not important' for ERP system implementation by users. The first CSF that was regarded as not important for ERP system implementation by users is 'organizational change management'. This finding of Reitsma and Hilletofth (2018) contradicts studies that discuss CSFs from a generic perspective (e.g., Aloini et al., 2007; Dezdar \& Sulaiman, 2009; Singla \& Goyal, 2006), which indicates that users believe that it is not needed for the implementing organization to utilize change management techniques and tools that must be defined and evaluated with the best practices in the industry. This contradicts the study of Deng and Gupta (2005), who argued that most users agree that change management and managing resistance is critical for information system implementation.

The second CSF that was regarded as not important for ERP system implementation by users is 'top management involvement'. This finding of Reitsma and Hilletofth (2018) contradicts studies that discuss CSFs from a generic perspective (e.g., Aloini et al., 2007; Dezdar \& Sulaiman, 2009; Sherer \& Alter, 2004), which indicates that users believe that the implementing organization's top management does not need to reinforce the commitment of all employees in the organization and create policies that determine and approve new organization structures, roles and responsibilities. They further suggest that users disagree with Snider et al. (2009), who argued that users appreciate management's sheer gesture to support their time in the ERP project. The finding of Reitsma and Hilletofth (2018) further suggests that users disagree with Ramadhana et al. (2016), who proposed that users are more likely to do their job and improve their performance through ERP system usage if there is support from top management.

The CSF framework of Reitsma and Hilletofth (2018) that includes 13 CSFs for ERP system implementation and the user perspective shows that there is a level of discrepancy and consensus between their study's user perspective and the traditional literature that discuss CSFs for ERP system implementation from a generic perspective.

\section{RESEARCH METHODOLOGY}

The aim of this study is to evaluate CSFs for ERP system implementation from a user perspective. In the first step of the research, it was necessary to set the scene by presenting relevant research from the research field. This literature review is based on the study of Reitsma and Hilletofth (2018), as they propose a framework consisting of thirteen CSFs for ERP system implementation and the user perspective (Table 1). In the second step of the research, a survey was conducted to identify the perspective of users towards the CSFs identified in the literature review. A questionnaire was developed based on the thirteen CSFs and each question contained a description of the corresponding CSF. The respondents were asked to grade each questionnaire item on a Likert-scale from one to five $(1=$ not important and $5=$ very important). The questionnaire was distributed within three organizations from Pakistan that recently had implemented an ERP system (Table 2).

The collected data was analysed with GRA to extract the most important CSFs from a user perspective. The higher the GRA value, the more emphasis the respondents put on the particular CSF. GRA is an impact evaluation model, which measures the degree of similarity, or difference between two sequences and is based on the grade of relation (Deng, 1986). When using GRA, a multi-criteria problem needs to be formulated by using a set of alternatives $\left(x_{1}, x_{2}, \ldots, x_{13}\right)$, in this study the CSFs, and criteria $\left(k_{1}, k_{2}, \ldots, k_{5}\right)$, in this study the Likert-style rating scale. Each criterion is assigned weightings and a preference index (PI). If a higher number of respondents choosing the value of each $k$ will have a positive impact on $x$, the PI is equal to one. Otherwise, it is equal to zero. Since $k_{1}$ and $k_{2}$ represent the Likert-style rating scales that indicates that users label the corresponding CSF is 'not important' or 'slightly important', $\mathrm{PI}_{1}$ and $\mathrm{PI}_{2}$ is equal to zero. $\mathrm{PI}_{3}$ represents the median Likert-style rating scale outcome 'moderately important' $\left(k_{3}\right)$ and is also equal to zero, as it not clearly indicates a positive outcome for $x$. $\mathrm{PI}_{4}$ and $\mathrm{PI}_{5}$ are equal to one, since they represent the Likertstyle rating scales 'important' $\left(k_{4}\right)$ and 'very important' $\left(k_{5}\right)$, which clearly indicate a positive outcome for $x$.

Table 2 Summary of demographic profile of respondents

\begin{tabular}{|l|c|c|c|}
\cline { 2 - 4 } \multicolumn{1}{l|}{} & Case organization $\boldsymbol{\alpha}$ & Case organization $\boldsymbol{\beta}$ & Case organization $\mathbf{Y}$ \\
\hline Organization location & Pakistan & Pakistan & Pakistan \\
\hline Organization type & Education & +-600 & +-2000 \\
\hline $\begin{array}{l}\text { Organization size in terms of } \\
\text { employees }\end{array}$ & +-1200 & 2014 & SAP ERP \\
\hline Implemented ERP system since & 2015 & Microsoft Dynamics & 870 \\
\hline ERP system provider & Microsoft Dynamics & 170 & 150 \\
\hline Number of ERP system users & 650 & 80 & 33 \\
\hline Number of distributed surveys & 250 & 24 & \\
\hline Response rate (\%) & 13 & & \\
\hline
\end{tabular}


Now that each criterion is assigned a PI, decision matrix D can be formulated:

$$
\mathrm{D}=\left\{\begin{array}{ccccc}
\mathrm{x}_{1}\left(\mathrm{k}_{1}\right) & \ldots & \mathrm{x}_{\mathrm{i}}\left(\mathrm{k}_{1}\right) & \ldots & \mathrm{x}_{\mathrm{m}}\left(\mathrm{k}_{1}\right) \\
\ldots & \ldots & \ldots & \ldots & \ldots \\
\mathrm{x}_{1}\left(\mathrm{k}_{\mathrm{j}}\right) & \ldots & \mathrm{x}_{\mathrm{i}}\left(\mathrm{k}_{\mathrm{j}}\right) & \ldots & \mathrm{x}_{\mathrm{m}}\left(\mathrm{k}_{\mathrm{j}}\right) \\
\ldots & \ldots & \ldots & \ldots & \ldots \\
\mathrm{x}_{1}\left(\mathrm{k}_{\mathrm{n}}\right) & \ldots & \mathrm{x}_{\mathrm{i}}\left(\mathrm{k}_{\mathrm{n}}\right) & \ldots & \mathrm{x}_{\mathrm{m}}\left(\mathrm{k}_{\mathrm{n}}\right)
\end{array}\right\}
$$

where:

$\mathrm{PI}_{\mathrm{j}}=\left\{\begin{array}{l}1, \text { Increasing } \\ 0, \text { Decreasing }\end{array}\right.$

Afterwards, matrix D' needed to be computed:

$\mathrm{D}^{\prime}=\left\{\begin{array}{ccccc}\mathrm{x}_{1}\left(\mathrm{k}_{1}\right)^{\prime} & \ldots & \mathrm{x}_{\mathrm{i}}\left(\mathrm{k}_{1}\right)^{\prime} & \ldots & \mathrm{x}_{\mathrm{m}}\left(\mathrm{k}_{1}\right) \\ \ldots & \ldots & \ldots & \ldots & \ldots \\ \mathrm{x}_{1}\left(\mathrm{k}_{\mathrm{j}}\right)^{\prime} & \ldots & \mathrm{x}_{\mathrm{i}}\left(\mathrm{k}_{\mathrm{j}}\right)^{\prime} & \ldots & \mathrm{x}_{\mathrm{m}}\left(\mathrm{k}_{\mathrm{j}}\right)^{\prime} \\ \ldots & \ldots & \ldots & \ldots & \ldots \\ \mathrm{x}_{1}\left(\mathrm{k}_{\mathrm{n}}\right)^{\prime} & \ldots & \mathrm{x}_{\mathrm{i}}\left(\mathrm{k}_{\mathrm{n}}\right)^{\prime} & \ldots & \mathrm{x}_{\mathrm{m}}\left(\mathrm{k}_{\mathrm{n}}\right)^{\prime}\end{array}\right\}$

where:

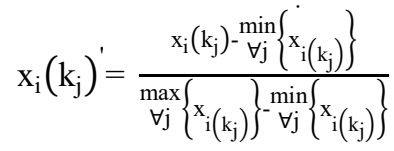

$\mathrm{y}_{0}=\left\{\mathrm{y}_{0\left(\mathrm{k}_{\mathrm{j}}\right)} ; \mathrm{k}=1,2,3, \ldots, \mathrm{m}\right\}$ was determined:

sequence

$\mathrm{y}_{0}\left(\mathrm{k}_{\mathrm{j}}\right)=\left\{\begin{array}{cc}\underset{\min }{\forall \mathrm{i}}\left\{\mathrm{x}_{\mathrm{i}}\left(\mathrm{k}_{\mathrm{j}}\right)\right\} & \text { if } \mathrm{PI}_{\mathrm{J}}=0 \\ \underset{\forall \mathrm{i}}{\max }\left\{\mathrm{x}_{\left.\mathrm{i}\left(\mathrm{k}_{\mathrm{j}}\right)\right\}}\right) & \text { if } \mathrm{PI}_{\mathrm{J}}=1\end{array}\right.$

The reference sequence $\mathrm{y}_{0}^{\prime}=\left\{\mathrm{y}_{0}\left(\mathrm{k}_{\mathrm{j}}\right)^{\prime}\right\} ; \mathrm{k}=1,2,3, \ldots, \mathrm{m}$ was computed by turning all decreasing criteria into opposite direction:

$$
\mathrm{y}_{0}\left(\mathrm{k}_{\mathrm{j}}\right)^{\prime}= \begin{cases}1-\mathrm{y}_{0\left(\mathrm{k}_{\mathrm{j}}\right)} & \text { if } \mathrm{PI}_{\mathrm{J}}=0 \\ \mathrm{y}_{0\left(\mathrm{k}_{\mathrm{j}}\right)} & \text { if } \mathrm{PI}_{\mathrm{J}}=1\end{cases}
$$

Finally, each sequence was compared with the reference sequence by calculating the grey relational coefficient: $\mathrm{y}\left(\mathrm{y}_{0}(\mathrm{k}), \mathrm{x}_{\mathrm{i}}(\mathrm{k})\right)=\frac{\Delta \min +\zeta \Delta \max }{\Delta_{\mathrm{oj}}(\mathrm{k})+\zeta \Delta \max } . \zeta$ serves as the equation's contrast control and the value of 0.5 is applied (Deng, 1986). The mean of the grey relational coefficient was used as the grey relational grade: $\mathrm{y}\left(\mathrm{y}_{0}\right.$, $\left.\mathrm{x}_{\mathrm{i}}\right)=\frac{1}{\mathrm{n}} \sum_{\mathrm{j}=1}^{\mathrm{n}} \mathrm{y}\left(\mathrm{y}_{0}(\mathrm{k}), \mathrm{x}_{\mathrm{j}}(\mathrm{k})\right)$. This made it possible to evaluate the user perspective towards CSFs for ERP system implementation and rank them in order of importance (Table 3).

\section{FINDINGS AND ANALYSIS}

The GRA values listed in Table $\mathbf{3}$ reveal that users from one case organization $(\alpha)$ label two CSFs as 'not important' for ERP system implementation, including minimum customization and performance measurement. All other CSFs have a GRA value above $\zeta 0.5$, meaning they are regarded as 'important' by case organizations $\alpha, \beta$, and $\gamma$.
However, the GRA values also indicate that different emphasis was put on each CSF. Therefore, based on their GRA value, the CSFs can be ranked in order of importance and labelled as either 'most important', 'important', or 'not important'.

The findings reveal that there is a level of consensus between the users from the three included case organizations, as they all label the same four CSFs for ERP system implementation as the 'most important'. The first CSF labelled as 'most important' is education and training (CSF12). This finding validates the study of Reitsma and Hilletofth (2018), where users also regarded education and training as 'most important' for ERP system implementation. This indicates that users agree that the implementing organization needs to prioritize education and training. This finding also validates the studies of Maguire et al. (2010), Umble et al. (2003), and Amoako-Gyampah (2004), who argued that users expect that training enhances their confidence and understanding of the ERP system, eliminating the need to allocate time to figuring out how the system should be used.

The second CSF labelled as 'most important' is strategic decision-making (CSF3). This finding validates the study of Reitsma and Hilletofth (2018), where users also regarded strategic decision-making as 'most important' for ERP system implementation. This finding can be explained with the study conducted by Woo (2007), who mention that users believe that senior managers should create a strategic approach to ERP system implementation. If they fail to do so, users will not understand the purpose and benefits of implementing the system and will be concerned about their benefits and position in the organization and how ERP would affect them (Woo, 2007).

The third CSF labelled as 'most important' is communication (CSF4), indicating that users agree that the implementing organization needs to prioritize effective communication during ERP system implementation, as it facilitates a structured manner for them to find out what is happening in the organization. This also indicates that users agree with Woo (2007), who stated that users want to know what is going on with the organization's ERP system implementation plans and benefits. Moreover, this finding could be explained with the study of Umble et al. (2003), who state that time will be wasted when it takes too much effort to find needed information.

The fourth and final CSF labelled as 'most important' by users is business process alignment (CSF9). This finding can be explained with the study conducted by Adam and O'Doherty (2000), who argued that users believe it is important that the goal of implementing a new ERP system should be to meet business requirements rather than trying to replicate functionality from legacy system(s)

When comparing these findings with the study conducted by Reitsma and Hilletofth (2018), users from both studies label education and training as well as strategic decision-making as 'most important'. However, this study also differs as users from the included case organizations label two additional CSFs as 'most important' (communication and business process alignment) and do not label any of the CSFs as 'not important'. 
Table 3 Ranking of the CSFs for ERP system implementation in order of importance

\begin{tabular}{|c|c|c|c|c|c|c|c|c|c|}
\hline & \multicolumn{3}{|c|}{ Case Organization a } & \multicolumn{3}{|c|}{ Case Organization $\beta$} & \multicolumn{3}{|c|}{ Case Organization y } \\
\hline Rank & CSF & GRA & Label $^{*}$ & CSF & GRA & Label & CSF & GRA & Label \\
\hline 1 & CSF3 & .827 & MI & CSF11 & .844 & MI & CSF12 & .882 & MI \\
\hline 2 & CSF5 & 807 & $\mathrm{Ml}$ & CSF10 & .802 & $\mathrm{Ml}$ & CSF13 & .832 & $\mathrm{Ml}$ \\
\hline 3 & CSF1 & .783 & $\mathrm{Ml}$ & CSF12 & .784 & $\mathrm{Ml}$ & CSF11 & .764 & $\mathrm{Ml}$ \\
\hline 4 & CSF4 & .727 & MI & CSF4 & .742 & $\mathrm{Ml}$ & CSF5 & .680 & $\mathrm{MI}$ \\
\hline 5 & CSF6 & .727 & MI & CSF3 & 690 & $\mathrm{Ml}$ & CSF3 & .667 & $\mathrm{Ml}$ \\
\hline 6 & CSF12 & 695 & $\mathrm{Ml}$ & CSF7 & 690 & $\mathrm{MI}$ & CSF4 & .620 & $\mathrm{Ml}$ \\
\hline 7 & CSF9 & 609 & MI & CSF2 & 667 & $\mathrm{Ml}$ & CSF2 & .614 & $\mathrm{Ml}$ \\
\hline 8 & CSF8 & .535 & $\mathrm{I}$ & CSF13 & 667 & $\mathrm{Ml}$ & CSF8 & .611 & $\mathrm{Ml}$ \\
\hline 9 & CSF2 & 528 & $\mathrm{I}$ & CSF6 & .667 & $\mathrm{MI}$ & CSF9 & .606 & $\mathrm{Ml}$ \\
\hline 10 & CSF10 & .514 & 1 & CSF9 & .660 & $\mathrm{MI}$ & CSF7 & .600 & $\mathrm{MI}$ \\
\hline 11 & CSF13 & .513 & I & CSF5 & 637 & 1 & CSF1 & .590 & 1 \\
\hline 12 & CSF7 & 442 & $\mathrm{NI}$ & CSF1 & .575 & $\mathrm{I}$ & CSF10 & 572 & $\mathrm{I}$ \\
\hline 13 & CSF11 & 431 & $\mathrm{NI}$ & CSF8 & 562 & I & CSF6 & 551 & 1 \\
\hline
\end{tabular}

*MI=most important, I=important and NI=not important

\section{CONCLUDING REMARKS}

This study aimed to investigate the user perspective towards CSFs for ERP system implementation. A survey was distributed within three organizations from Pakistan to evaluate 13 CSFs for ERP system implementation from a user perspective. The findings revealed that users from case organization $\alpha$ regarded two CSFs as not important for ERP system implementation, including minimum customization and performance measurement. All other CSFs were regarded as important by users from case organization $\alpha, \beta$, and $\gamma$. However, the analysis indicates that different emphasis was put on the 13 CSFs. Users from all three case organizations regarded the following four CSFs as 'most important' for ERP system implementation: (1) education and training, (2) strategic decision-making, (3) communication, and (4) business process alignment. The CSFs education and training and strategic decision-making were also regarded as 'most important' for ERP system implementation by users surveyed by Reitsma and Hilletofth (2018). This means that users from both studies believe that they need to be offered adequate education and training by the implementing organization. Furthermore, the implementing organization needs to prioritize having a clear understanding of the strategic goals for ERP system implementation and key people throughout the organization need to have a clear, compelling vision of how the organization should operate behind the implementation effort.
This study has both practical and theoretical implications. Even though researchers highlight the important role users play during ERP system implementation, their perspective towards the widely discussed CSFs for ERP system implementation has not been investigated comprehensively. Reitsma and Hilletofth (2018) attempted to fill this gap by evaluating 13 CSFs for ERP system implementation from a user perspective. However, within their study they investigated the perspective of users from one German manufacturer and thus the empirical research needed to be extended. This study extends aforementioned research to Pakistan and identified gaps and similarities between this study's findings and the findings of Reitsma and Hilletofth (2018). The generated insights into the user perspective facilitates the design of more effective ERP systems, its more successful implementation and improved management. During ERP system implementation, the project team can use the insights to improve the system's adoption.

As in all research, it is important to acknowledge its limitations. One limitation of this study is that it considers thirteen CSFs without grouping them according to different stages or phases of ERP system implementation. Another limitation is that study only evaluates existing CSFs for ERP system implementation. These limitations should be considered when researchers attempt to replicate or further test the reported findings and each of these limitations can be addressed by further research. The next step of this research could be to distribute the survey to more ERP system users in other organizations, countries and industries. If further 
research provides similar findings, it would be interesting to conduct qualitative research that aims to identify underlying reasons why users perceive the presented CSFs in the way they do. Perhaps cultural differences affect how users evaluate certain CSFs and maybe they propose CSFs that do not exist within the literature.

\section{REFERENCES}

Adam, F., and O'Doherty, P. (2000). Lessons from enterprise resource planning implementations in Ireland - towards smaller and shorter ERP projects. Journal of Information Technology 15 (4), pp. 305-316.

Akkermans, H., and van Helden, K. (2002). Vicious and virtuous cycles in ERP implementation: A base study of interrelations between critical success factors. European Journal of Information Systems 11, pp. 35-46.

Aloini, D., Dulmin, R., and Mininno, V. (2007). Risk management in ERP project introduction: review of the literature. Information Management 44 (6), pp. 547-567.

Amoako-Gyampah, K. (2004). ERP implementation factors: A comparison of managerial and user perspectives. Business Process Management Journal 10 (2), pp. 171-183.

Bingi, P., Sharma, M. K., and Godla, J. (1999). Critical issues affecting an ERP implementation. Information Systems Management 16 (2), pp. 7-14.

Chang, B., Kuo, C., Wu, C. H., and Tzeng, G. H. (2014). Using fuzzy analytic network process to assess the risk in Enterprise Resource Planning system implementation. Applied Soft Computing 28, pp. 196-207.

Davenport, T. (2000). Mission critical: Realizing the promise of enterprise systems. Harvard Business School Press, Boston, Massachusetts.

Deng, J. L. (1986). The stability of the grey linear system. International Journal of Control 43 (1), pp. 313-320.

Deng, H., and Gupta, P. (2005). Critical success factors for information systems implementation: An end-user perspective. Proceedings of the 2005 Information Resources Management Association International Conference.

Dezdar, S., and Sulaiman, A. (2009). Successful enterprise resource planning implementation: Taxonomy of critical factors. Industrial Management \& Data Systems 109 (8), pp. 10371052 .

Eichhorn, B. R., and Tukel, O. I. (2016). A review of user involvement in Information System projects. Project Management: Concepts, Methodologies, Tools, and Applications: Concepts, Methodologies, Tools, and Applications 1.

Fearon, C., Manship, S., McLaughlin, and H., Jackson, S. (2013). Making the case for "techno-change alignment": A processual approach for understanding technology- enabled organisational change. European Business Review 25 (2), pp. 147-162.

Gargeya, V. B., and Brady, C. (2005). Success and failure factors of adopting SAP in ERP system implementation. Business Process Management Journal 11 (9).

Hilletofth, P. (2008). Differentiated supply chain strategy: Response to a fragmented and complex market, Licentiate thesis, Chalmers University of Technology, Gothenburg, Sweden.

Hilletofth, P., Hilmola, O.-P., and Ujvari, S. (2010). Teaching ERP in logistics curriculum: A case experience from Sweden. International Journal of Business Information Systems 6 (3), pp. 295-314.

Hilletofth, P., and Lättilä, L. (2012). Agent based decision support in the supply chain context. Industrial Management \& Data
Systems 112 (8), pp. 1217-1235.

Huang, S. M., Chang, I. C., Li, S. H., and Lin, M. T. (2004). Assessing risk in ERP projects: Identify and prioritize the factors. Industrial Management \& Data Systems 104 (8), pp. 681-688.

Maguire, S., Ojiako, U., and Said, A. (2010). ERP implementation in Omantel: A case study. Industrial Management \& Data Systems 110 (1), pp. 78-92.

Motwani, J., Subramanian, R., and Gopalakrishna. (2005). Critical factors for successful ERP implementation: Exploratory findings from four case studies. Computers in Industry 56 (6), pp. 529-544.

Mu, E., Kirsch, L. J., and Butler, B. S., (2015). The assimilation of enterprise information system: An interpretation systems perspective. Information \& Management 52 (3), pp. 359-370.

Ramadhana, B. A., Govindaraju, R., and Wibisono, Y. Y. (2016). ERP system usage and panoptic control: The role of perceived organizational support. Proceedings of the 2016 IEEE IEEM, Bali, Indonesia.

Reitsma, E., and Hilletofth, P. (2018). Critical success factors for ERP system implementation: A user perspective. European Business Review 30 (3), pp. 285-310.

Rosario, J. G. (2000). On the leading edge: Critical success factors in ERP implementation projects. Business World (Philippines), 27

Saini, S., Nigam, S., and Misra, S. C., (2013). Identifying success factors for implementation of ERP at Indian SMEs: A comparative study with Indian large organizations and the global trend. Journal of Modelling in Management 8 (1), pp. 103-122.

Sherer, S. A., and Alter, S. (2004). Information system risks and risk factors: Are they mostly about information systems. Communications Association Information Systems 14, pp. 29 64.

Singla, A. R., and Goyal, D. P. (2006). Management risk factors in design and implementation of ERP systems: An empirical investigation of the Indian industry. Journal of Advances in Management Research 3 (1), pp. 59-67.

Snider, B., da Silveira, G. J., and Balakrishnan, J. (2009). ERP implementation at SMEs: Analysis of five Canadian cases. International Journal of Operations \& Production Management 29 (1), pp. 4-29.

Stedman, C. (1999). Survey: ERP costs more than measurable ROI. Computerworld 33 (6).

Umble, H., Haft, R., and Umble, M. (2003). Enterprise Resource Planning: Implementations and critical success factors. European Journal of Operational Research 146, pp. 241-257.

Upadhyay, P., and Dan, P. K. (2009). ERP in Indian SME's: A post implementation study of the underlying critical success factors. International Journal of Management Innovation Systems 1 (2), pp. 1-10.

Wang, R. Y. (1998). A product perspective on total data quality management. Communications of the ACM 41 (2), pp. 58-65.

Wee, S. (2000). Juggling toward ERP success: Keep key success factors high, ERP News.

Woo, H. S. (2007). Critical success factors for implementing ERP: The case of a Chinese electronics manufacturer. Journal of Manufacturing Technology Management 18 (4), pp. 431-442.

Young, H. K., Jane, P., Boo, Y. C., and Saumyendu, G. (2012). Understanding users' acceptance of Enterprise Resource Planning (ERP) system in project-based sectors. IEEE Transactions on Engineering Management 59 (2).

Ziemba, E., and Oblak, I. (2013). Critical success factors for ERP systems implementation in public administration. Proceedings of the Informing Science \& Information Technology Education Conference 1, pp. 1-19. 
Ewout Reitsma (MSc) is a PhD candidate at Jönköping University in Sweden. His research agenda consists of various subjects including new product development, supply chain management, three-dimensional concurrent engineering, and information systems.

Per Hilletofth (PhD) is a Professor of Operations and Supply Chain Management at Jönköping University in Sweden. His research focuses on demand-supply integration, operations strategy, supply chain relocation, product development, and decision support. He has editorial assignments in several international journals.

Umer Mukhtar (MS) is an Assistant Professor at GIFT University and a PhD candidate at University of Management and Technology in Pakistan. His research interest includes marketing and supply chain management. He also has ten years of industry experience in the textile sector in Pakistan. 